\title{
Association of different uncus lesions on magnetic resonance imaging with epilepsy
}

\section{Manyetik rezonans görüntülemede saptanan farklı unkus lezyonlarının epilepsi ile ilişkisi}

Bilge Öztoprak¹, Burhanettin Çiğdem²

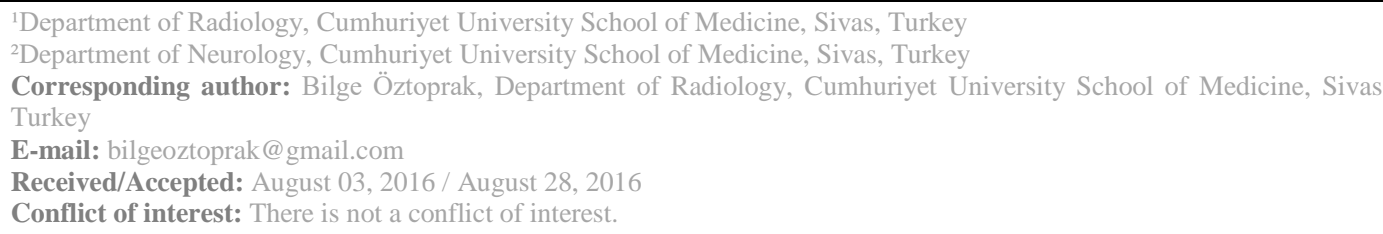

\section{SUMMARY}

Objective: Uncus is the hook-like most anteromedial portion of the parahippocampal gyrus and is a part of the limbic system. It is the only gyrus, together with the amygdala, that contains nuclei and is associated with seizures accompanied by olfactory hallucinations. The aim of this study is to examine the relationship between different uncus lesions detected by magnetic resonance imaging (MRI) and epilepsy/seizures.

Method: 33 patients with unilateral or bilateral uncus lesions on MRI obtained between March 2008 through May 2014 were enrolled in the study. MR images and clinical charts of patients were retrospectively investigated for MRI findings and presence of epilepsy/seizures.

Results: Bilateral uncus involvement was observed in herpes encephalitis $(n=5)$, autoimmune limbic encephalitis $(n=2)$, mesial temporal sclerosis $(n=3)$, metastasis $(n=1)$ and Rasmussen encephalitis $(n=1)$, whereas unilateral involvement of the uncus was seen in glial tumors $(n=4)$, metastases $(n=4)$, mesial temporal sclerosis $(n=4)$, cavernous angioma $(n=2)$, dysembryoplastic neuroepithelial tumor (DNET, $n=5)$, herpes encephalitis $(n=1)$, and autoimmune limbic encephalitis $(n=1)$. Epilepsy/seizures were present in two-thirds of patients. However, none of the 5 patients with a metastatic uncus lesion showed epilepsy/seizures.

Conclusions: Many uncus pathologies can be detected by MRI and most of them are associated with epilepsy.

Keywords: Epilepsy, Hippocampus; Magnetic resonance imaging; Uncus; Uncinate gyrus 


\section{ÖZET}

Amaç: Parahipokampal girusun çengel șeklindeki anteromedial kısmı olan unkus, limbik sistemin bir parçasıdır. Amigdala ile birlikte nükleus içeren tek girus parçası olup olfaktör halüsinasyonların eşlik ettiği epilepsiler ile ilişkilidir. Bu çalışmada manyetik rezonans görüntüleme (MRG) ile saptanan farklı unkus lezyonlarının klinik olarak epilepsi ile ilişkileri araştırılmıştır.

Yöntem: Mart 2008- Mayıs 2014 tarihleri arasında kranial MRG'de tek taraflı ya da iki taraflı unkus lezyonu saptanan 33 hastanın lezyonları ve dosyaları retrospektif olarak incelendi. Klinik olarak epilepsi/nöbet varlığı ve MR bulguları ile ilișkisi değerlendirildi.

Bulgular: Çalışmaya alınan 33 hastanın 12'sinde (\%36) iki taraflı, 21 'inde (\%64) tek taraflı unkal lezyon vardi. Herpes ensefaliti $(n=5)$, otoimmün limbik ensefalit $(n=2)$, mezial temporal skleroz $(n=3)$, metastaz $(n=1)$ ve Rasmussen ensefaliti $(n=1)$ bilateral tutulum yaparken, glial tümör $(n=4)$, metastaz $(n=4)$, mezial temporal skleroz $(n=4)$, kavernöz anjiom $(n=2)$, disembrioplastik nöroepitelyal tümör $(n=5)$, herpes ensefaliti $(n=1)$ otoimmün limbik ensefalit $(n=1)$ ise tek taraflı unkal lezyonlara neden olmuştu. Hastaların 2/3'ünde epilepsi/nöbet mevcuttu, ancak unkus metastazı olan 5 hastada epilepsi/nöbet görülmedi.

Sonuç: MRG ile unkus tutulumu yapan pek çok değişik patoloji saptanmakta olup unkus lezyonlarının büyük bölümü epilepsi ile ilişkilidir.

Anahtar sözcükler: Epilepsi; Hipokampus; Manyetik rezonans görüntüleme; Unkus; Unsinat girus

\section{INTRODUCTION}

The hippocampus is the inferomedial part of the temporal lobe of brain which is responsible for the memory and emotional functions, spatial orientation and learning ${ }^{1,2}$. Uncus, also called the uncinate gyrus, is the most medial part of the parahippocampal gyrus and it is the connection between the medial hippocampus and the amygdala. It is a part of the limbic system which is primarily responsible for the emotional functions ${ }^{3,4}$. It also involves the olfactory cortex and is responsible for seizures with olfactory or gustatory hallucinations ${ }^{5,6}$. Another major clinical consequence related to uncus is herniation in a case of a space-occupying lesion, especially located in the middle cranial fossa ${ }^{7}$.

On MRI normal uncus has a somewhat lower signal on T1- and a higher signal on T2-weighted images compared to the other parts of the brain. This may lead to wrong interpretation of bilateral hyperintensities as pathologic, or conversely, bilateral diffuse lesions may sometimes be overlooked radiologically if the observer is unfamiliar with this normal appearance of the uncus. On the other hand, unilateral lesions are relatively easy to depict although they may clinically be silent. Many intracranial pathologies may affect uncus and most of them are diagnosed radiologically with MRI. The aim of this study is to assess the relationship of different uncus lesions detected with MRI with seizures.

\section{MATERIAL AND METHODS} Patient selection

This study was approved by the institutional ethics committee. Clinical data and radiologic images of patients with uncus lesions on MRI between 2008 and 2014 were retrospectively analyzed. Patients with infarction, tumors occupying a large area including the uncus such as GBM or lymphoma, widespread diseases such as confluent ischemic brain lesions and diffuse atrophy including Alzheimer's disease were excluded to eliminate the bias on whether the clinical signs and symptoms were related to uncus lesions or other parts of the brain involved in these disease states. Patients with MR images of low quality, such as motion or metallic susceptibility artifacts, were also excluded. A total of 33 patients with unilateral or bilateral involvement of the uncus on MRI were examined for the radiological and clinical findings.

Image Acquisition and Data Analysis The MRI examinations were done with two 1.5 Tesla MRI units (Magnetom Aera, Siemens, Erlangen, Germany and 
Excelart Pianissimo, Toshiba, Tokyo, Japan) using 20-channel phased array head coil and standard head coil, respectively. Diffusion-weighted images were acquired using echo planar imaging (EPI) sequences. The parameters used for image acquisition by each MR device (Siemens and Toshiba, respectively) were as follows: axial and sagittal T1weighted spin echo (SE) ( TR: 520 and $550 \mathrm{~ms}$; TE: 5.6 and $15 \mathrm{~ms}$; FA: $150^{\circ}$ and 70/180' ; NEX: 3 and 1.2; FOV: $220 \times 84$ and $220 \times 180 \mathrm{~mm}$; matrix: $256 \times 100$ and $256 \times 160$; slice thickness: 5 and $5 \mathrm{~mm}$; interslice gap: 1.7 and $1 \mathrm{~mm}$ ); axial and coronal, T2-weighted fast SE (TR: 4400 and $5000 \mathrm{~ms}$; TE: 102and $94 \mathrm{~ms}$; FA: $150^{\circ}$ and 90/180 ; NEX: 2 and 2; FOV: $220 \times 97$ and $220 \times 180 \mathrm{~mm}$; matrix: $320 \times 90$ and $320 \times 224$; slice thickness: 5 and $5 \mathrm{~mm}$; interslice gap: 1.7 and $1 \mathrm{~mm}$ ) and axial fluid-attenuated inversion recovery (FLAIR) (TR: 8000 and 7500 ms, TE: 86 and 94 ms, TI: 2384 and 2200 ms; FA: 150 and 90/160; NEX: 1 and 1; FOV: $220 \times 97$ and $220 \times 180 \mathrm{~mm}$; matrix: $256 \times 100$ and $256 \times 160$; slice thickness: 5 and $5 \mathrm{~mm}$; interslice gap: 1.7 and $1 \mathrm{~mm}$ ). In patients with known or suspected epilepsy, a T1-weighted FLAIR sequence in axial and coronal planes (TR: 5390 and $4800 \mathrm{~ms}$; TE: 15 and $18 \mathrm{~ms}$; TI: 500 and $800 \mathrm{~ms}$; FA: $150^{\circ}$ and $160^{\circ}$; NEX: 1 and 1.2; FOV: $200 \times 100$ and $220 \times 180 \mathrm{~mm}$; matrix: $256 \times 100$ and $256 \times 160$; slice thickness: 3 and $5 \mathrm{~mm}$; interslice gap: 1.7 and $1 \mathrm{~mm}$ ) and thinsection angled coronal T2weighted/FLAIR images at right angles to the longitudinal axis of hippocampus were also included. Susceptibilityweighted images were also available in some of the MRI examinations. Axial and coronal T1-weighted intravenous contrast-enhanced images were obtained with a $0.1 \mathrm{mmol} / \mathrm{kg}$ intravenous paramagnetic agent (gadolinium-DTPA or gadodiamide) in patients with an indication for contrast administration, such as a tumor or an infection.

Brain MR images of the patients were evaluated to characterize uncus lesions. Bilateral and unilateral involvement were noted. In addition, the clinical charts of the patients included in the study were searched for the presence of seizures and these findings were correlated with the MRI findings. Chi-square test was used to assess the difference between laterality of lesions in terms of clinical findings. The significance level was set at $p<0.05$.

\section{RESULTS}

Fifteen $(45.5 \%)$ patients were male and $18(54.5 \%)$ patients were female. The mean age of the subjects was $46.6 \pm 20.0$. Demographic, imaging and clinical findings are briefly summarized in Table 1. 
Table 1. Demographic, clinical and imaging data of patients.

\begin{tabular}{|c|c|c|c|c|c|}
\hline No & Age & Gender & Involvement & Diagnosis & Epilepsy/ seizures \\
\hline 1 & 26 & Female & Unilateral & Mesial temp. scler. & + \\
\hline 2 & 31 & Male & Unilateral & DNET & + \\
\hline 3 & 18 & Female & Bilateral & Herpes encephalitis & + \\
\hline 4 & 34 & Female & Bilateral & Limbic encephalitis & - \\
\hline 5 & 66 & Female & Bilateral & Herpes encephalitis & + \\
\hline 6 & 49 & Female & Unilateral & DNET & + \\
\hline 7 & 43 & Male & Unilateral & Cavernoma & - \\
\hline 8 & 21 & Female & Unilateral & Mesial temp. scler. & + \\
\hline 9 & 33 & Female & Unilateral & Glial Tm & + \\
\hline 10 & 56 & Male & Unilateral & Cavernoma & - \\
\hline 11 & 72 & Female & Bilateral & Metastasis & - \\
\hline 12 & 18 & Male & Unilateral & Limbic encephalitis & + \\
\hline 13 & 84 & Female & Bilateral & Herpes encephalitis & - \\
\hline 14 & 69 & Female & Unilateral & Glial tm & + \\
\hline 15 & 54 & Female & Bilateral & Limbic encephalitis & - \\
\hline 16 & 53 & Male & Unilateral & DNET & + \\
\hline 17 & 49 & Female & Bilateral & Rasmussen encephalitis & + \\
\hline 18 & 43 & Male & Unilateral & DNET & + \\
\hline 19 & 48 & Male & Unilateral & Glial tm & + \\
\hline 20 & 53 & Male & Unilateral & Metastasis & - \\
\hline 21 & 20 & Male & Unilateral & Mesial Temp Scl. & + \\
\hline 22 & 33 & Female & Unilateral & Metastasis & + \\
\hline 23 & 27 & Female & Unilateral & Glial tm & + \\
\hline 24 & 58 & Female & Unilateral & Mesial temp. scler. & + \\
\hline 25 & 32 & Male & Bilateral & Herpes encephalitis & + \\
\hline 26 & 27 & Male & Unilateral & Metastasis & - \\
\hline 27 & 59 & Female & Bilateral & Mesial temp. scler. & - \\
\hline 28 & 73 & Male & Unilateral & Herpes encephalitis & - \\
\hline 29 & 84 & Male & Bilateral & Mesial temp. scler. & + \\
\hline 30 & 22 & Male & Unilateral & DNET & + \\
\hline 31 & 78 & Female & Bilateral & Herpes encephalitis & + \\
\hline 32 & 67 & Female & Unilateral & Metastasis & - \\
\hline 33 & 38 & Male & Bilateral & Mesial temp. scler. & + \\
\hline
\end{tabular}

Mesial temp. Scler. :Mesial temporal sclerosis, DNET: Dysembryoplastic neuroepithelial tumor 


\section{CMJ Original Research September 2016, Volume: 38, Number: 3}

Cumhuriyet Medical Journal

$211-218$

Twelve (36\%) patients had bilateral, 21 $(64 \%)$ patients had unilateral uncus involvement. Herpes encephalitis $(n=5)$, autoimmune limbic encephalitis $(n=2)$, mesial temporal sclerosis $(n=3)$, metastasis $(n=1)$ and Rasmussen encephalitis $(n=1)$ caused bilateral uncus lesions. Unilateral involvement of the

uncus was seen in glial tumors $(n=4)$, metastases $(n=4)$, mesial temporal sclerosis $(n=4)$, cavernous angioma $(n=2)$, dysembryoplastic neuroepithelial tumor (DNET, $n=5)$, herpes encephalitis $(\mathrm{n}=1)$, and autoimmune limbic encephalitis $(n=1)$ (Figs 1-6).
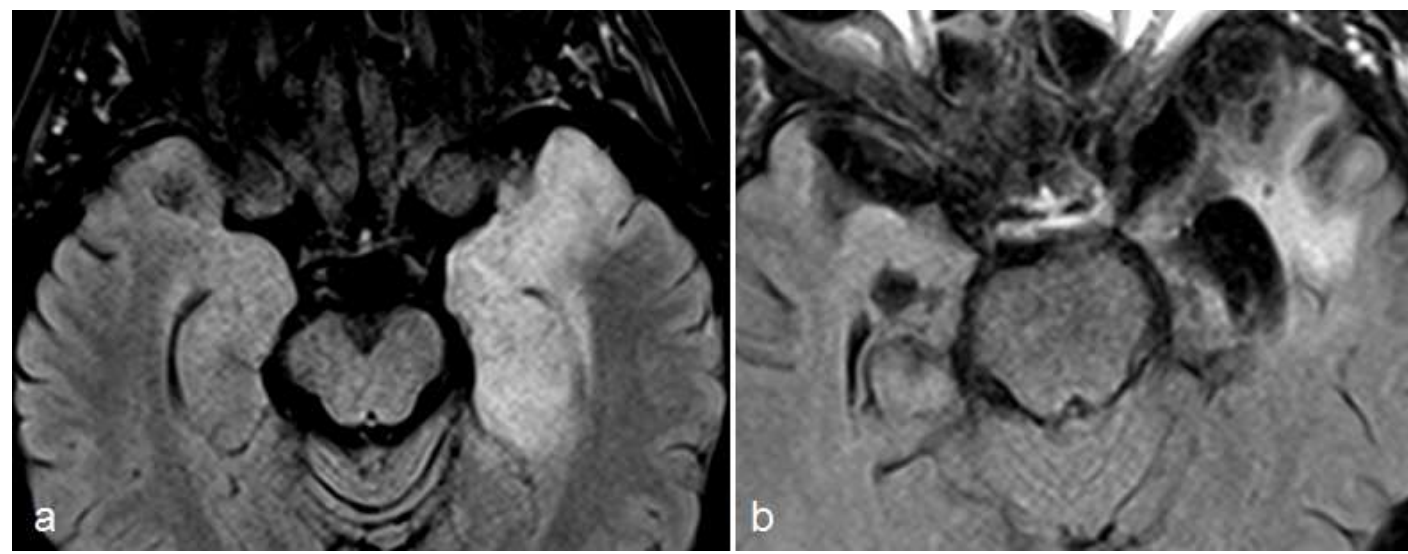

Figure 1. a. Herpes encephalitis mainly affecting the left uncus b. Bilateral sequelae of herpes encephalitis in the form of atrophy and gliosis.

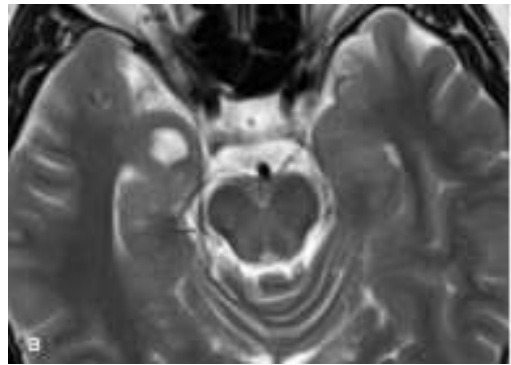

Figure 2. Axial T2-weighted (a), T1-weighted coefficient map (c) show a DNET in the right uncus.
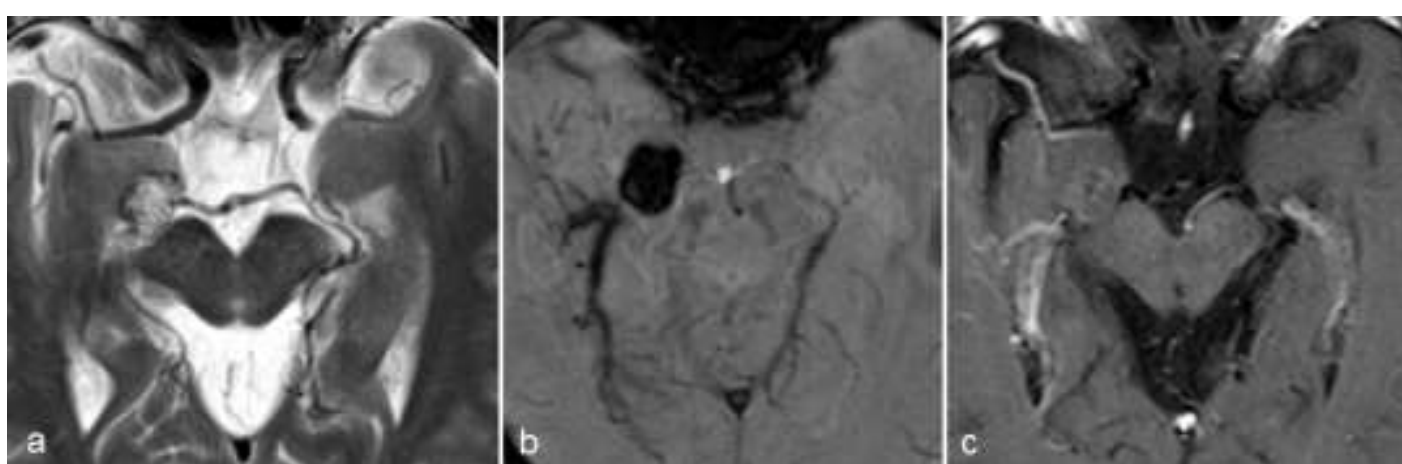

Figure 3. Axial T2-weighted (a), susceptibility-weighted and contrast-enhanced T1weighted images reveal a cavernoma in the right uncus. 


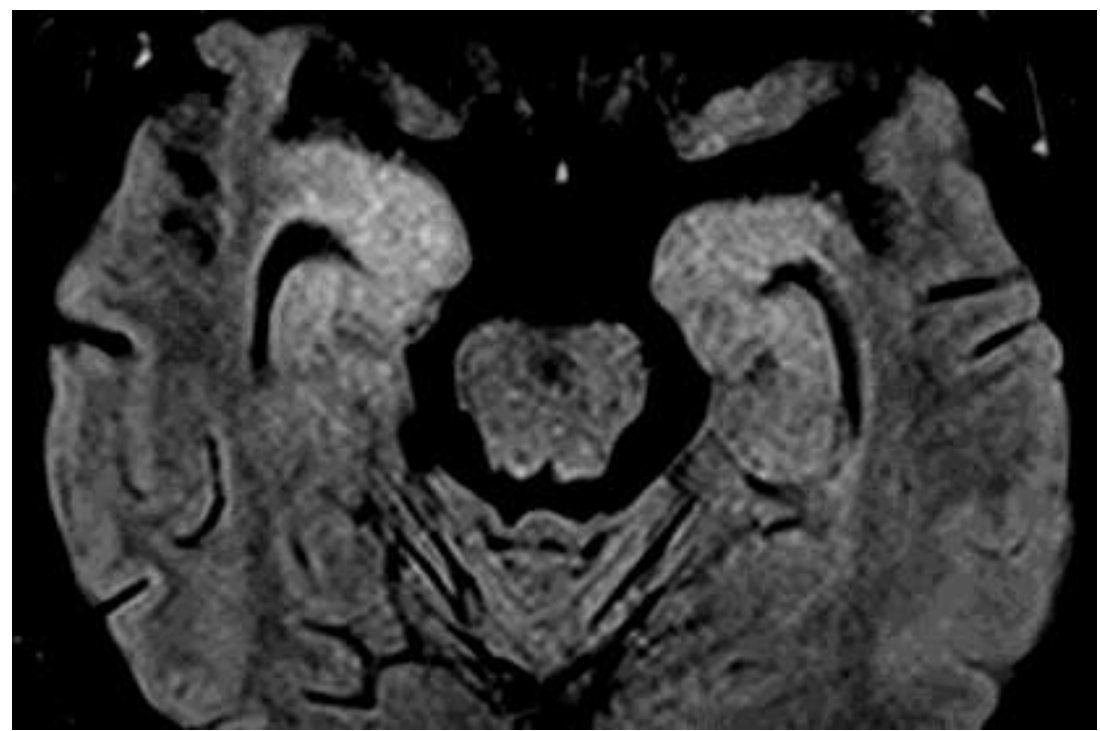

Figure 4. Axial FLAIR image shows autoimmune limbic encephalitis

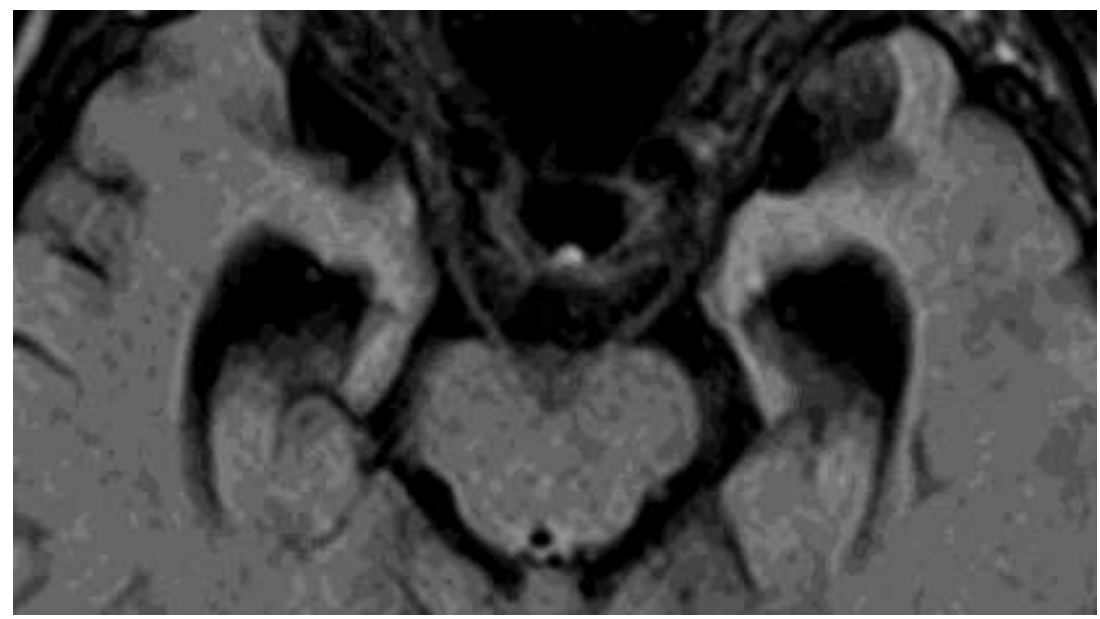

Figure 5. Bilateral mesial temporal sclerosis is seen in axial FLAIR image.

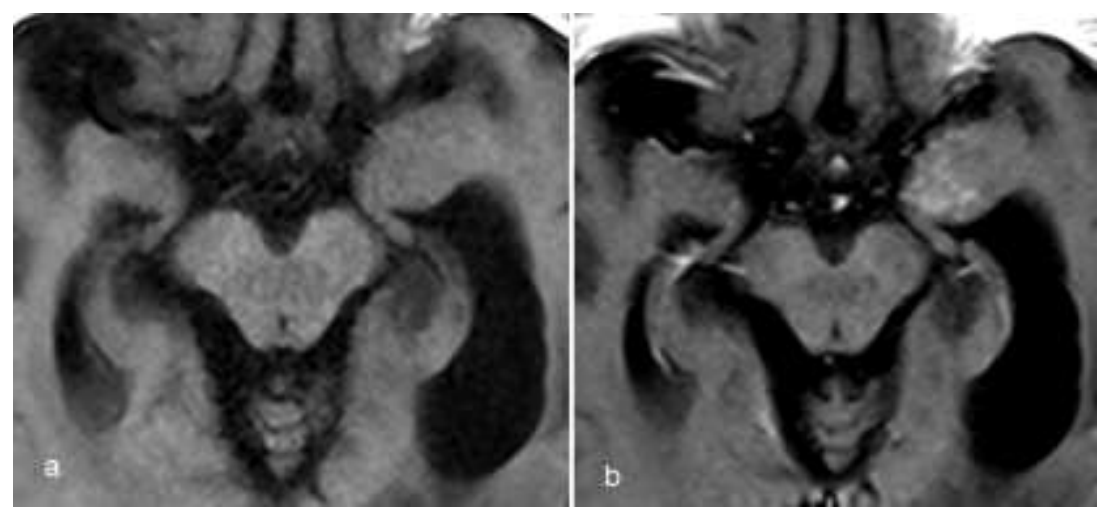

Figure 6. T1-weighted axial image (a) shows a Grade II astrocytoma on the left uncus which is more apparent after contrast administration (b).

Epilepsy/seizures were present in 22 $(67 \%)$ of patients. There was no statistically significant difference between unilateral and bilateral uncus involvement in terms of occurrence of seizures $(\mathrm{p}=0,443)$. 


\section{DISCUSSION}

Uncus is a part of the medial temporal lobe which has not been studied and understood well. Although hippocampus and epilepsy is still a hot topic, especially in terms of treatment of intractable epilepsy, relation of epilepsy with uncus lesions are not well-documented ${ }^{8-12}$. We think uncus is located in a very strategic point where the hippocampus, amygdala and parahippocampal gyrus meet. Thus, hypothetically, it may participate in many disease states other than known disorders of uncus such as olfactory dysfunction, cognitive impairment and seizures with olfactory and gustatory hallucinations ${ }^{13,14}$.

Epilepsy/seizures were present in twothirds of all patients although a very small number of patients were present in each subgroup of diagnosis. This result may suggest that MR examination should be done if seizures are seen in the adult age group to uncover the underlying etiology.

In only one of 33 patients, there was an olfactory hallucination accompanying seizures, although uncus is involved in all patients. Since medial temporal lobe structures are small and executed by each other, as in the case of hippocampusuncus-amygdala complex, the lesion in the uncus was extending to adjacent temporal lobe structures in most cases. Although patients with lesions sitting with their largest portion in the uncus were enrolled in this study, that is, the lesion can easily be concluded to be an uncus lesion even at the first gaze, origin of the seizures may be the hippocampus and this may be the reason why most of the fits were not associated with olfactory or gustatory hallucinations.

Medial temporal lobe is a site of predilection for DNET, mesial temporal sclerosis and herpes encephalitis which are known to be highly associated with epilepsy ${ }^{15,16}$. The great majority of these patients (15 of 18 patients) in the current study are shown to experience epilepsy/seizures. Other glial tumors, named as 'limbic tumors' if located in the medial temporal lobe, showed a lower ratio of accompanying seizures ${ }^{17}$.

Epilepsy is seen in 20-40\% and is commonly the first presenting symptom in patients with brain metastases ${ }^{18}$. None of the five patients with a metastatic lesion in the uncus experienced epilepsy or any kind of seizures. Patient number is very small to conclude a negative association between metastases and seizures, however, this result may pave the way to a prospective trial to investigate the presence or absence of abnormal electrical discharges in patients with uncus metastases.

Some limitations of this study are that epilepsy and simple seizures were not evaluated separately and not in all patients it was possible to obtain the exact origin of the seizure activity, although we know that there was a lesion in the temporal lobe. Due to the retrospective design of the study, healthy controls were not enrolled.

Epilepsy/seizures are seen in the majority of uncus lesions, despite it remains to be investigated whether the abnormal electrical activity starts from the uncus or not.

\section{REFERENCES}

1. Leuner B, Gould E. Structural Plasticity and Hippocampal Function. Annu Rev Psychol 2010; 61: 111-40.

2. Kieman JA. Anatomy of the temporal lobe. Epilepsy Res Treat 2012 (2012); Article ID: 176157 doi: 10.1155/2012/176157

3. Murty V, Calabro F, Luna B. The role of experience in adolescent cognitive development: Integration of executive, memory, and mesolimbic systems. Neurosci Biobehav Rev 2016 pii: S01497634(16)30160-2 doi: 10.1016/j.neubiorev.2016.07.034

4. Papinutto N, Galantucci S, Mandelli ML, Gesierich B, Jovicich J, Caverzasi E, Henry RG, Seeley WW, Miller BL, Shapiro KA, GornoTempini ML. Structural connectivity of the human anterior temporal lobe: 
A diffusion magnetic resonance imaging study. Hum Brain Mapp 2016; 37: 22-10-22.

5. Mackay FH. Uncinate fits. Can Med Assoc J 1924; 14: 233-235

6. Mizobuchi M, Ito N, Tanaka C, Sako K, Sumi Y, Sasaki T. Unidirectional olfactory hallucination associated with ipsilateral unruptured intracranial aneurysm. Epilepsia 1999; 40: 516-9.

7. Lin HS, Tsai CC, Chang CK, Chen SJ. Giant intracranial mesenchymal chondrosarcoma with uncal herniation. Formosan Journal of Surgery 2012; 45: 93e96.

8. Usui N. Current topics in epilepsy surgery. Neurol Med Chir 2016; 56: 228-35.

9. Park HR, Chung HT, Lee SK, Kim DG, Paek SH. Fractionated stereotactic gamma knife radiosurgery for medial temporal lobe epilepsy: A case report. Exp Neurobiol 2016; 25: 93-101.

10. JettéN, Sander JW, Keezer MR. Surgical treatment for epilepsy: the potential gap between evidence and practice. Lancet Neurol 2016; 15: 982-94.

11. Sindou M, Guenot M. Surgical anatomy of the temporal lobe for epilepsy surgery. Adv Tech Stabd Neurosurg 2003; 28: 315-43.

12. Zentner J, Hufnagel A, Wolf HK, Ostertun B, Behrens E, Campos MG, Solymosi L, Elger CE, Wiestler OD, Schramm J. Surgical treatment of temporal lobe epilepsy: clinical, radiological, and histopathological findings in 178 patients. J Neurol Neurosurg Psychiatry 1995; 58: 66673.

13. Cross DJ, Anzai Y, Petrie EC, Martin N, Richards TL, Maravilla KR, Peskind ER, Minoshima S. Loss of olfactory tract integrity affects cortical metabolism in the brain and olfactory regions in aging and mild cognitive impairment. J Nucl Med 2013; 54: 1278-84.

14. Garcia-Casares N, Jorge RE, GarciaArnés JA, Acion L, Berthier ML, Gonzales-Alegre P, Nabrozidis A, Gutiérrez A, Ariza MJ, Rioja J, Gonzaléz-Santos P. Cognitive dysfunctions in middle-aged type 2 diabetic patients and neuroimaging correlations: a cross-sectional study. J Alzheimers Dis 2014; 42: 1337-46.

15. Kawamura $Y$, Nakayama A, Kato $T$, Miura $\mathrm{H}$, Ishihara $\mathrm{N}$, Ihira $\mathrm{M}$, Takahashi Y, Matsuda K, Yoshikawa T. Pathogenic role of human herpesvirus $6 \mathrm{~B}$ infection in mesial temporal lobe epilepsy. J Infect Dis 2015; 212: 1014-21.

16. Ranger A, Diosy D. Seizures in children with dysenmbrioplastic neuroepithelial tumors of the brain-A review of surgical outcomes across several studies. Childs Nerv Syst 2015; 31: 847-55.

17. Capizzano AA, Kirby P, Moritani T. Limbic Tumors of the Temporal Lobe: Radiologic-Pathologic Correlation. Clin Neuroradiol. 2015; 25: $127-35$.

18. Maschio M. Brain Tumor-Related Epilepsy. Curr Neuropharmacol 2012; 10: 124-33. 